DOI: 10.2478/RAE-2019-0020 Review of Artistic Education no. 172019 189-195

\title{
4. THE FEMALE ARTIST IN ROMANIAN INTER-WAR THEATER
}

\author{
Carmen Antochi ${ }^{173}$
}

\begin{abstract}
In Romania at the beginning of the twentieth century women were concerned with the home environment. In an urban environment, however, there had been a re-alignment towards education, women from affluent families having an artistic preoccupation, with them being determined and epochal. Though loved and admired on the stage, the women who embraced an artistic career were not looked upon with total respect by the society as a whole, because they were straying away from 'their calling'. The opening towards the occident had lit the flame in our womens hearts to reach equality in rights, to occupy a place in society and to fight a prejudice image.
\end{abstract}

Key words: the female artist, feminism, inter-war theatre

\section{Introduction}

During the inter-war period, Romania knew a cultural blossoming without precedent, a true rebirth of artistic and intellectual life, under the influence of the tendencies which showed themselves on European stages. Even though, just like everywhere else, men where the ones leading, feminism starts becoming more prevalent in Romania, having the backing of some elite liberal politics, but especially the contribution of women to the moral education of the people, their willingness to sacrifice for their nation and their family, being in fact excluded from public life, the right to vote being acquired only in 1929 and only for local elections. The constitution of 1939 and the Electoral Law have solidified the right to vote for women, who were about thirty years of age, but in autocratic conditions, this right having not been practically exercised until after 1945 .

Today, history paints a picture which intrigues: a noble class - generically represented by boyars, which, in fact, had for a long time young peoples 'access to the world of theater and music, considering that these arts constitute an exclusively foreign territory; 'it was something lowly for the boyars, to see their sons, grabbing their bow, because they thought it is a job given only to gypsies ${ }^{174}$, something unheard of and totally degrading, for someone to get on the theater stage, considering the one becoming an actor, as a man without a strong head, as a comedian [...] During that time the Romanian woman actress was looked upon as a lost woman.' (Burada 1915, 89-90) Actors were disconsidered, not even being received in front of judges, this aspect being

\footnotetext{
173 Doctoral Candidate, "George Enescu" National University of Arts from Iaşi, Romania, email: happycrow@yahoo.com

${ }^{174}$ Gheorghe Burada, son of governor Teodor Burada, was the first Romanian artist, son of a Moldovan boyar, who in 1852, went on the stage of the National Theater of Iasi, violin in hand, playing Beriot Concerto op. 16, with piano accompanienment (see Grigore Burada, biography, Iasi, 1904).
} 
recorded in Pravila lui Andronachi Donici, being published in Iasi in 1814 (Burada 1915, 90). Even though, on Romanias territory, there were multiple theater troupes, they were performing in either French, German, Greek or Russian, Even the very first plays on Romanians territory were in foreign languages, because as Gheorghe Asachi used to say, at the beginning of the eighteenth century and the beginning of the nineteenth century the mother language 'was only spoken in sheep pens.'

\section{Discussions}

The first theatrical performance in Romanian dates back to 1816 when Gheorghe Asachi, at his own expense, set up a theater company in the houses of Hatman Costachi Ghica, in which 'the first theater play in Romanian was presented: Mirtil and Hloe, pastoral in an act, worked by Gheorghe Asaki himself, after Gesner and Florian. The children of Ghika and Sturza have played the roles of this play; these were: Mrs. Şubin was born Ghika into the role of the pastor Hloe, prince Ghika in the role of shepherd Mirtil and Costachi Sturdza in the role of Lizie the worshiper of Amor' (Burada 1915, 99). Immediately afterwards, these performances were forbidden by the church because 'they were lighting a fire in young people's minds', but this interruption did not last long. On November 15, 1836, a Dramatic philharmonic conservatory was established in Iasi, where 12 girls in the morning and 16 boys in the afternoon were enrolled in the first year (Burada 1915, 167-168). Fortunately, in Romania, women's access to the stage was not forbidden, but admission to the Conservatory of Music and Dramatic Art was made for both girls and boys only with the consent of the parents.

The interwar period was marked by a strong effervescence of the Romanian theater. The directors of theaters had strongly supported the worthy actors; subsidies were granted to actors - and especially for actresses - as an aid for the purchase of toiletries, subsidies that exceeded the monthly salary, also determined by the fact that the premieres were quickly going one after another on stage theaters, each performance having only a few performances. Thus, in 1920, Mihai Codreanu - the director of the National Theater in Iasi - proposed to send to Paris two of the remarkable actors of the stage: Sorana Tyopa and Aurel Ghiţescu, which was done with great efforts in 1924, at the realization of this project contributing Mihail Sadoveanu and C.B. Penescu, the next director of the theater.

Women have had an important say in setting up private theater companies, especially in those particularly difficult times in the private theater. At the beginning of the 1919-1920 season, the 'Excelsior' Company was founded at the "Modern" Theater, where signed was an 'association agreement' between Elvira Popescu, Ion Manolescu, Al. Mihalescu, I. Iancovescu, G. Storin, Al. Buzescu, on the basis of 'equal camaraderie both in wins and losses' (I. Massoff, Teatrul românesc - privire istorică, vol. V 1974, 207). With the establishment of 
the ' Mic Theater' ('Little Theater') in 1921, the 'Elvira-Iancovescu-Mihalescu' company was born, in which the three - Elvira Popescu, Ion Iancovescu and Alexandru Mihaescu were co-directors. Also at the Mic Theater in 1926 the foundations of 'Tantzi Cutava Company - Mişu Fotino' are planted (Massoff, Teatrul românesc - privire istorică, vol. VI 1974, 103).

In 1924 the 'Bulandra-Manolescu-Maximilian-Storin Company' was founded (a new and refreshed formula of the company that had been born since 1910 - 'Davila Company' and had many changes over time) and Marioara Voiculescu sets up her own theater in a former cinema hall. 'Marioara Cinsky Constantin Tănase Company' play magazine plays, enticing the audience with their current twists, which were the subject of close supervision by the Police Prefecture. Referring to the female artists' condition, especially in stage space, we have to notice a woman's tendency to gain access to areas designed, in a way almost discreetly, for men, such as dramaturgy and direction.

Hortensia Papadat-Bengescu, although not in his first theater work, debuts on the stage of the Bucharest National Theater in 1921 with the social comedy in four stages Bătrânul (I. Massoff, Teatrul românesc - privire istorică, vol. V 1974, 251). On the same stage and in the same year, Igena Fioru begins his dramaturgy, but 'who did not enjoy the solicitude theatre-side. Having him play takes off the poster because the proceeds have fallen below budget; the writer had to go to the Court of Appeal, which gave him a win.' (I. Massoff, Teatrul românesc - privire istorică, vol. V 1974, 216) In 1924 Riki-Tiki-Tavi by Zoe Verbiceanu (Massoff, Istoria Teatrului National din Bucuresti: 1877-1937 1937, 232) and Păcatul by Lucreția Petrescu (Massoff, Istoria Teatrului National din Bucuresti: 1877-1937 1937, 234) are shows, in 1926 Ucenicul vrăjitor by Ștefania Zotoviceanu (Massoff, Istoria Teatrului National din Bucuresti: 18771937 1937, 237), in 1932 Șapte gâște by Claudia Minulescu. Still here have mentioned Constanța Hodoș was one of the representatives of the feminist movement in Romania, a theater writer and, especially, children's theater.

If in the first part of the interwar period women's access was easier, with the passage of time they were easily removed, which made Sorana Topa act to restrain herself from signing the real name to her play, using the nickname Niculae Bucur instead. We consider relevant a statement of the actress Sorana Thopa, related to the National theatre Bucharest: 'After another, sand leakage on the hourglass, the time, a new work needed to be expressed also on paper: Călătorie-n întuneric [...] I read it to some close friends, both writers, who urged me to show it to the National Theater [...] It was accepted even with the prospect of being in the repertoire of the same season.

As times were troubled, Rebreanu made the express condition that he accepted the pseudonym and the rest - but a meeting between him and the author was a major necessity, and there were other delicate issues: distribution, staging... I consented (director, by mutual agreement, Șahighian was chosen). In brackets it was said - then a political interference in other areas was not unusual. 
So, one autumn afternoon, I took the way to the theater at the meeting time, but not without a touch of emotion. When I entered the cabinet, the hall was empty. I sat silently on a chair - the staff of the institution was still on vacation - alone and curiously looked at by the head of the cabinet ... 'Do you have an audience now?' He asked. 'Yes,' I replied. The look was sharply intrigued (how was she not kept in the loop?). After a silence, looking at my watch, I got up quickly, and started heading towards the massive, leather-lined front door. 'But, lady...', sought the cabinet chief to keep me. I had already crossed the threshold into the office of Rebreanu, who was sitting at his desk and writing. Having seen me, he looked at me long and somewhat unpleasantly surprised ...

- What's wrong, ma'am?... Is something so urgent?

- 'In a way, yes, Director,' I said with a low voice. And as his gaze provoked me, I said, 'I know you're waiting for someone else. I'm sorry... But I'm the character you are expecting. '

- How? ...

- Yeah, you have Niculae Bucur in front of you.

He suddenly rose up, tall, massive as he was; he sketched a slightly backward step. It had overwhelmed him, the unpredictable news had shocked him. After a lingering silence, I resumed smiling: 'I knew I was going to make you disappointed, but that's the truth, what can we do?' Very rich to talk and reactions as he was, he hurried back, and with a gesture, too broad to protest, he said,

- But it's not true, but on the contrary, I'm glad, but...

- 'But... Did your expectation was for it to be a man?' Or maybe a colleague of the Transylvanian guild? And not to see that a woman comes in who is also an actress?

The answer, then received silences him. It needs so little - vanity to be flattered, and even a recognition of completeness has been enough to give rise to a stupid self-delusion lasting for years and years... The premiere of the play took place on the evening of March 14, 1943 under the chosen pseudonym. It was only later that the real name appeared on the poster. ' (T,opa Anul V, nr. 3/4 (46/47), 1994, 12-13)

In the 1930-1931 season, the troupe 'Masca' (Râpeanu 1974, 476), whose animators were George Mihail Zamfirescu and Tatiana Nottara, was the initiator of popular theater performances and performances for children, especially with Romanian songs, at the popular atheneums of the capital with a short life with just a few shows (Massoff, Teatrul românesc - privire istorică, vol. VI 1974, 384-385). In terms of involvement in the director's work, things are much more difficult. Research on Romanian women's history - directors in Romania, are few, timid and insufficiently documented.

If we accept as a reference point the first generation of professional directors of the Direction Faculty established at the Institute of Theater and Cinematography in Bucharest in 1948, among its first graduates there are 
Marietta Sadova, Jeni Acterian, Sorana Coroama-Stanca, Sanda Manu and others, then we can consider having a precursorial period and an officially recognized period. Looking at the truth, however: prejudices still persist. Regarding the stage of the precursors, because the role of the director was not fully defined, we are at first in a mixed direction. Lucia Sturdza-Bulandra recounts in her Memoirs that "in the permanent group there were 132 actors: men 72, women 60. In performance: 16 women, 3 men. Directors: 8 . Painters: 14.

\section{Results}

The number of directors was very small, because we worked for a very long time without a director. Each of us, who felt capable of doing it, directed one play in turn. We did not feel the need for a foreign intervention to explain the text, to teach us the phrasing, etc. We ourselves were experienced actors. [...] In Bulandra Company, for a long time, the one who was acting was supervising the room, drew attention to the interpretations to be reviewed, gave advice on how to proceed to alleviate certain deficiencies.

At Bulandra Theater, directorial work has long been a collective work. That's why, although there was almost no play for me in which I wouldn't completely involve myself, I cannot remember any one whose directorship has been exclusive to me. However, Ion Massoff notes that during the 1927-1928 theatrical season, 'a play by English playwright Noel Coward - Familia Bliss (Weekend), directed by Lucia Sturdza-Bulandra, was for the first time in Romanian' (Massoff, Teatrul românesc - privire istorică, vol. VI 1974, 155).

As the director's role is shaping up, we are already seeing shows completely directed by women. Ioan Massoff gives us some clues in his anthology about the Romanian theater: 'Under Agathei Bârsescu's directorship, on November 16, 1926, Medeea by Ernest Legouve were performed, played by Agatha Bârsescu, Aurel Ghiţescu (Creon), Stelian Morcovescu-Teleajen (Iason), Iancu Profir (Orfeu), Ani Braeschi (Creuza), Natalia Profir; Agatha Bârsescu was applauded and was given flowers' (Massoff, Teatrul românesc - privire istorică, vol. VI 1974, 119).

To these concerns are added two others, with equally strong impact in the evolution of Romanian theatrical art: in the field of scenography and theatrical critique. Thus, Lucia Sturdza-Bulandra confirms that she has many abilities, including being a stage designer, the decor of Therese Raquin by Zola being executed according to her instructions, according to the scenario. However, besides Florica Scîrțan who made the costumes for Lorenzaccio by Alfred de Musset, 'of great beauty (the action of the play takes place in one of the most fastuous ducal courtyards of the Italian Renaissance,' (Massoff, Teatrul românesc - privire istorică, vol. VI 1974, 150), I have not met other names in our research until after World War II, except for Elena Barlo, which we have seen since 1925 as a creator of decorative and opera costumes, declared by 
critics of the period to be "truly fastuous", in 1927, being the only participating woman to participate in exhibition of theater models organized by the 'Hasefer' bookstore (Massoff, Teatrul românesc - privire istorică, vol. VI 1974, 109).

Alice Voinescu, drama writer, she became a professor of aesthetics and history of theater at the Dramatic Art Conservatory in Bucharest in 1922. Between 1932 and 1942 she made a series of radio conferences on cultural and feminist subjects and from 1936 she would focus only on the theater and dramatic representations (Alice Voinescu 2018). We can not pass without reminding of Dina Cocea, with theater studies in Paris and her debut in the theater also in Paris in 1934, and who, between 1941 and 1949, was the director of 'Teatrul Nostru' ('Our Theater') and 'Studioul Teatrului Nostru' ('Our Theater Studio') Bucharest.

\section{Conclusions}

On January 12, 1931, the Romanian Union of the Universal Society of the Theater was founded, coordinated in 14 sections, two of which were directed by women: Dramaturgy Section (Ion Minulescu), Critics (Emil D. Fagure), Theatrical Press (Scarlat Froda and Dem. Theodorescu), Staging (Soare Z. Soare), Singers (G. Folescu), Teaching (I. Nonna Otescu), Actors (Maria Filotti), Composers (M. Jora), Orchestra (George Georgescu), Radiophony (Andrian Maniu), Decor and Costumes (Traian Cornescu), Law (Alexandru Kiriţescu), Choreography (Floria Capsali), Administrative (Al. Buzescu), President: Emil D. Fagure; Vice-Presidents: Maria Filotti, I. Nonna Otescu (Massoff, Teatrul românesc - privire istorică, vol. VI 1974, 351).

We consider that in our research, we have identified only a small part of the female artists who worked during the interwar period, their contribution to the development of theatrical creation, the flourishing of Romanian intellectual and artistic life being a significant one.

\section{References}

1. Alice Voinescu. 910 2018. https://ro.wikipedia.org/wiki/Alice_Voinescu (accessed 10 25, 2018).

2. Burada, Teodor T. Istoria teatrului în Moldova. Volumul 1. Iași: Institutul de arte grafice N.V. Ștefaniu \& Comp., 1915.

3. Constanța Hodoș. $2018 \quad 03 \quad 2018$. https://ro.wikipedia.org/wiki/Constan\%C8\%9Ba_Hodo\%C8\%99 (accessed 10 8, 2018).

4. Dina Cocea. $28 \quad 10 \quad 2018$. https://ro.wikipedia.org/wiki/Dina_Cocea_(actri\%C8\%9B\%C4\%83_din_Rom\% C3\%A2nia) (accesat 112,2018 ).

5. Massoff, Ioan. Istoria Teatrului National din Bucuresti: 1877-1937. București: Editura Librăriei „Universala” ALCALAY \& Co., 1937. 
6. Massoff, Ion. Teatrul românesc - privire istorică, vol. V. VIII volume. București: Minerva, 1974.

7. Massoff, Ion. Teatrul românesc - privire istorică, vol. VI. VIII volume. București: Minerva, 1974.

8. Râpeanu, Valeriu. „Note şi comentarii.” În Mărturii în contemporaneitate, de George Mihail Zamfirescu. București: Editura Minerva, 1974.

9. Sturdza-Bulandra, Lucia. Amintiri...amintiri... București: Editura de Stat pentru Literatură și Artă, 1956.

10. Tieghem, Philippe van. Mari actori ai lumii. București: Editura Meridiane, 1969.

11. Țopa, Sorana. „Sorana Țopa - Par-elle-même.” Apostrof, revistă a uniunii scriitorilor, Anul V, nr. 3/4 (46/47), 1994. 